\title{
Rancang Bangun Sistem Pengukuran Tekanan Udara Menggunakan DT-Sense Barometric Pressure Berbasis Internet of Things dengan Tampilan pada Smartphone
}

\author{
Indah Tri Handini ${ }^{(1, a)^{*}}$, Yulkifi $^{(1, b)}$, dan Yenni Darvina ${ }^{(2, c)}$ \\ Jurusan Fisika, Universitas Negeri Padang, Padang, Indonesia, 25132 \\ Email :(a*)indahthandini@gmail.com, ${ }^{(b)}$ yulkifliamir@gmail.com, ${ }^{(c)}$ ydarvina@yahoo.com
}

Diterima (29 Juli 2019), Direvisi (29 Januari 2020)

\begin{abstract}
Weather is very important to observe. One of the weather paramaters is air pressure. The air pressure on a surface is the force given to a surface or area by the air column above the surface. This research designed an air pressure gauge using DT-Sense Barometric Pressure which used to measure the value of the air pressure based of Internet Of Things with measurement result displayed on a smartphone. For data retrieval techniques were done by directly and indirectly. The amount that carried out directly is air pressure, while the indirect amount is the precision and the accuracy of air pressure measurements. The result of this research was the system performance specifications consist of mechanical systems that were supported by electronic systems. The precision measurements were done by comparing the results from Digital Barometer with the air pressure gauge that has been made. The percentage of average erros that obtained was $0.02965 \%$, the relative precision average on the system was 0.99955 , and the precision percentage of the tool was very good at $99.995 \%$. The accuracy measurements were done by measuring the air pressure under the same conditions. The measurements were done by 10 times with reading on a constant standard measuring tools. The average accuracy of the system was 0.99 with an average standard deviation of 0.7 and relative errors average $0.0098 \%$.
\end{abstract}

Keywords: air pressure, DT-Sense Barometric Pressure, Digital Barometer, Internet of Things .

Abstrak. Cuaca menjadi hal yang sangat penting untuk diamati.Salah satu parameter cuaca yaitu tekanan udara.Tekanan udara pada suatu permukaan adalah gaya yang diberikan kepada suatu permukaan atau area oleh sekolom udara di atas permukaan tersebut. Penelitian ini mendesain alat ukur tekanan udara menggunakan DT-Sense Barometric Pressure yang digunakan untuk mengukur nilai tekanan udara berbasis Internet of Things dengan hasil pengukuran ditampilkan pada smartphone. Teknik pengambilan data dilakukan secara langsung maupun secara tidak langsung. Besaran yang dilakukan secara langsung yaitu tekanan udara, sedangkan besaran yang tidak langsung adalah ketepatan dan ketelitian pengukuran tekanan udara. Hasil penelitian ini yaitu spesifikasi performansi sistem terdiri dari sistem mekanik yang ditunjang oleh sistem elektronik. Ketepatan pengukuran dilakukan dengan cara membandingkan hasil dari Barometer Digital dengan alat ukur tekanan udara yang telah dibuat. Persentase ketepatan alat sangat baik yaitu $99.995 \%$. Ketelitian pengukuran dilakukan dengan mengukur tekanan udara pada kondisi yang sama. Pengukuran dilakukan sebanyak 10 kali dengan pembacaan pada alat ukur standar konstan. Ketelitian rata-rata sistem yaitu 0.99 dengan standar deviasi rata-rata yaitu 0.7 dan kesalahan relatif rata-rata $0.0098 \%$.

Kata kunci: tekanan udara, DT-Sense Barometric Pressure, Barometer Digital, Internet of Things.

\section{PENDAHULUAN}

Tekanan udara di suatu permukaan merupakan gaya yang diberikan oleh sekolom udara diatas permukaan tersebut. Tekanan yang diberikan sebanding dengan massa udara vertikal yang terdapat di atas permukaan sampai pada batas 
ketinggian lapisan atmosfer terluar [1]. Pada umumnya semakin tinggi suatu daerah dari permukaan laut maka tekanan udaranya semakin berkurang. Tekanan udara akan semakin rendah apabila ketinggian bertambah [2].

Nilai tekanan udara menjadi parameter penting dalam meteorologi. Data tekanan udara dapat dipergunakan sebagai data untuk menentukan tingkat kepadatan udara dari suatu daerah yang merupakan data vital untuk pelayanan penerbangan dan analisa isobar. Nilai tekanan udara merupakan karakteristik udara yang dapat meramalkan cuaca suatu daerah. Apabila nilai tekanan udara suatu daerah jauh dari nilai tekanan udara normal maka diramalkan disekitar daerah tersebut akan terjadi badai [3].

Terdapat beberapa instrumen yang biasa digunakan untuk pengamatan parameter cuaca, salah satunya yaitu Barometer Digital. Beberapa stasiun BMKG menggunakan Barometer Digital dalam mengukur tekanan udara. Dalam penggunaan Barometer Digital, jika terjadi kerusakan operator akan mengalami kesulitan dalam memperbaikinya. Hal ini disebabkan karena rangkaian dasar pembangun sistemnya tidak diketahui. Barometer Digital ini juga memiliki harga yang terlalu mahal.

Sesuai dengan ketentuan World Meteorological Office (WMO), alat untuk mengukur parameter cuaca harus memiliki tingkat keakuratan yang tinggi. Berdasarkan hal tersebut, tingkat keakuratan atau ketelitian dari masingmasing peralatan yang digunakan dalam pengamatan meteorologi sangat penting untuk diketahui [4]. Saat ini informasi yang akurat dengan update secara realtime sangat diperlukan. Proses pemantauan cuaca konvensional biasanya menggunakan seperangkat sensor yang dipasang pada suatu lokasi. Metode konvensional ini menyebabkan kesulitan untuk menempatkan perangkat sensor yang sulit dijangkau. Maka dari itu sistem wireless lebih mudah dan efisien untuk pengukuran karena operator tidak harus dekat dengan alat sehingga dapat diamati dari jarak yang jauh [5]. Salah satu solusinya yaitu merancang alat ukur tekanan udara menggunakan DT-Sense Barometric Presssure berbasis Internet of Things dengan hasil pengukuran dapat ditampilkan pada smartphone.

\section{TEORI DASAR}

\section{DT Sense Barometric Pressure and Temperature Sensor (DT-SBPT)}

Sensor merupakan sebuah perangkat yang menerima stimulus dan direspon dengan suatu sinyal listrik. Melalui sebuah sensor dapat dirancang berbagai sistem yang dapat bekerja secara otomatis dan juga dapat menganalisa fenomenafenomena yang terjadi dialam [6]. DT Sense Barometric Pressure and Temperature Sensor (DT-SBPT) adalah sebuah modul sensor berbasis sensor HP03 yang dapat digunakan untuk mengukur besarnya tekanan dan suhu udara di sekitar sensor. Modul ini dilengkapi dengan antarmuka UART TTL serta keluaran data yang telah berbentuk digital sehingga tidak perlu perhitungan yang terlalu banyak [7]. Bentuk fisik dari modul sensor HP03SA dapat diperhatikan pada Gambar 1.

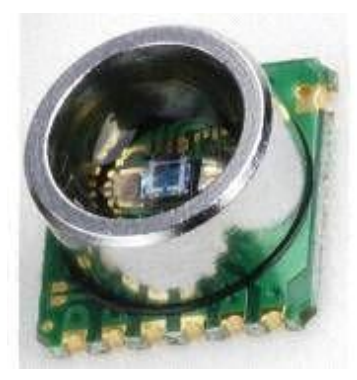

Gambar 1. Bentuk fisik Sensor HP03SA 


\section{Internet of Things}

Pengiriman data yang terbaca oleh sensor menggunakan teknologi Internet of Things. Internet of Things adalah jaringan benda fisik yang tertanam dengan perangkat lunak, sensor, dan konektivitas lainnya untuk mencapai nilai dan layanan yang lebih besar dengan cara bertukar data dengan pabrikan, operator, atau perangkat lainnya [8]. Sistem pengukuran tekanan udara ini tampilan datanya ditampilkan pada smartphone. Smartphone merupakan telepon genggam yang mempunyai kemampuan tinggi dengan fungsi yang hampir menyerupai komputer [9]. Smartphone dapat menampilkan data dari sensor serta mengolah data tersebut sehingga data sensor dapat diakses oleh semua orang. Hal ini merupakan salah satu konsep dari perkembangan teknologi internet yang dikenal dengan Internet of Things.

\section{NodeMCU ESP8266}

Board NodeMCU sudah dilengkapi dengan fitur wifi dan firmwarenya yang bersifat opensource. NodeMCU berukuran sangat kecil dengan panjang $4.83 \mathrm{~cm}$, lebar $2.54 \mathrm{~cm}$, dan dengan berat 7 gram. Selain itu NodeMCU juga memiliki harga yang relatif terjangkau [11]. Board NodeMCU dapat dilihat pada Gambar 2.

Salah satu firmware modul ESP8266 yang bersifat open-source dan terdapat development kit untuk memudahkan membangun prototipe produk Internet of Things (IoT) [10].

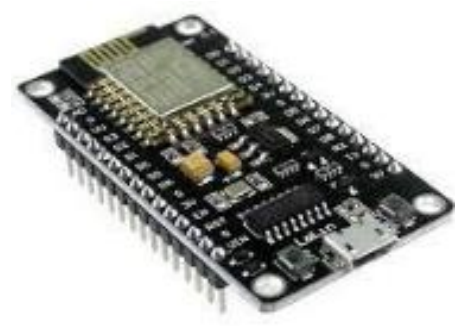

Gambar 2. Board NodeMCU ESP8266
NodeMCU diprogram menggunakan software Arduino IDE. Arduino IDE (Integrated Development Environment) merupakan software yang telah disiapkan oleh arduino bagi para perancang untuk melakukan berbagai proses yang berkaitan dengan pemrograman arduino [12].

\section{ThingSpeak}

Cloud yang digunakan pada sistem ini adalah ThingSpeak. ThingSpeak merupakan platform IoT yang memungkinkan kita untuk mengumpulkan, menyimpan, menganalisis, mem-visualisasikan, dan bertindak atas data dari sensor atau aktuator. ThingSpeak berfungsi sebagai pengumpul data yang mengumpulkan data dari perangkat node dan juga memungkinkan data yang akan diambil ke dalam lingkungan perangkat lunak untuk analisis historis data [13].

\section{METODE PENELITIAN}

Metode penelitian dapat dijelaskan melalui blok diagram sistem, desain mekanik, dan desain perangkat lunak sistem.

\section{Blok Diagram}

Sistem pengukuran tekanan udara ini terdiri dari blok transmitter dan blok receiver. Pada blok trasmitter terdapat catu daya, sensor tekanan udara dan NodeMCU. Sedangkan pada blok receiver terdapat ThingSpeak dan smartphone. Catu daya berfungsi untuk mengaktifkan sistem. DT-Sense Barometric Pressure digunakan sebagai sensor tekanan udara. Sensor ini akan dihubungkan dengan NodeMCU. Sensor diprogram dengan menggunakan bahasa pemrograman Arduino dan ditanam dalam 
mikrokontroler NodeMCU. Terdapat program yang akan menghubungkan dengan jaringan Wifi yang ada. Setelah terhubung data akan dikirim ke Web ThingSpeak.com. Data yang terkirim ke ThingSpeak selanjutnya diambil dan ditampilkan pada smartphone. Setelah itu tampilan pada smartphone diprogram dengan menggunakan aplikasi App Inventor dan displaynya ditampilkan pada smartphone. Blok diagram sistem dapat dilihat pada Gambar 3, skematik rangkaian sistem dapat dilihat pada Gambar 4, dan rancangan sistem pengukuran tekanan udara ini dapat diperlihatkan pada Gambar 5.

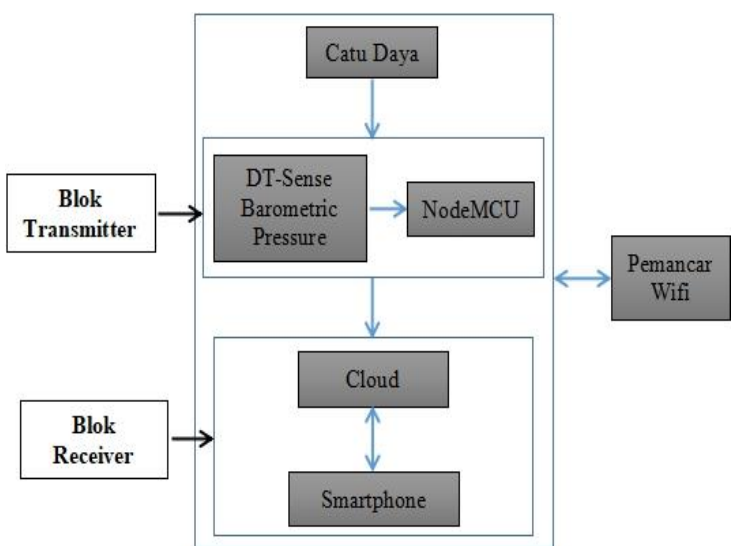

Gambar 3. Blok Diagram Sistem

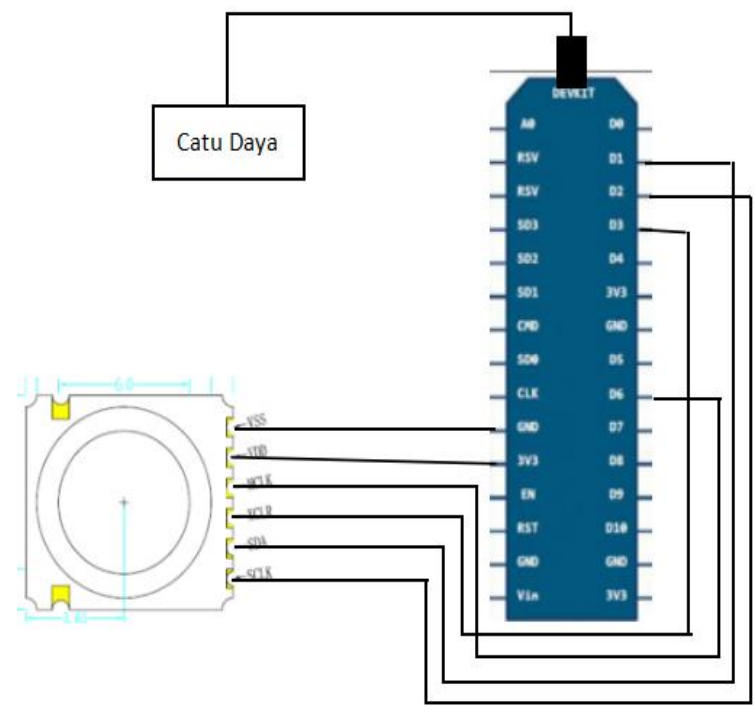

Gambar 4. Skematik Rangkaian

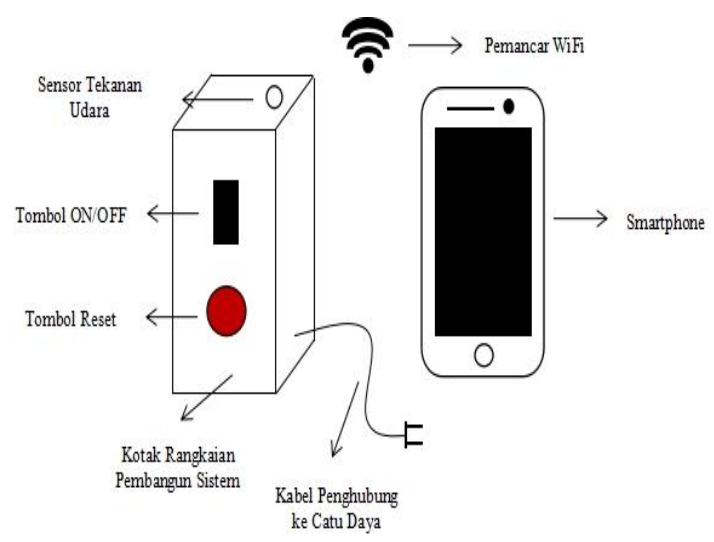

Gambar 5. Desain Mekanik Sistem

Desain mekanik pada penelitian ini terdiri dari sensor tekanan udara, kotak rangkaian yang berisi NodeMCU, tombol ON/OFF, tombol Reset dan kabel penghubung alat ke catu daya. Cara kerja sistem pengukuran tekanan udara ini yaitu pada saat sistem terhubung dengan Wifi maka data sensor tekanan udara akan terbaca dan dikirim ke Web ThingSpeak.com. Data sensor tekanan udara diambil di ThingSpeak dan ditampilkan di smartphone.

\section{Desain Perangkat Lunak}

Desain perangkat lunak untuk sistem pengukuran tekanan udara sangat diperlukan agar kinerja yang dihasilkan sesuai dengan harapan. Diagram alir perangkat lunak yang akan dibuat pada sistem pengukuran tekanan udara menggunakan DT-Sense Barometric Pressure terbagi atas 2 bagian yaitu desain perangkat lunak pada NodeMCU ESP8266 dan desan perangkat lunak pada App Inventor. Desain perangkat lunak dari App Inventor dapat dilihat pada Gambar 6 dan desain perangkat lunak pada NodeMCU ESP8266 dapat dilihat pada Gambar 7. 


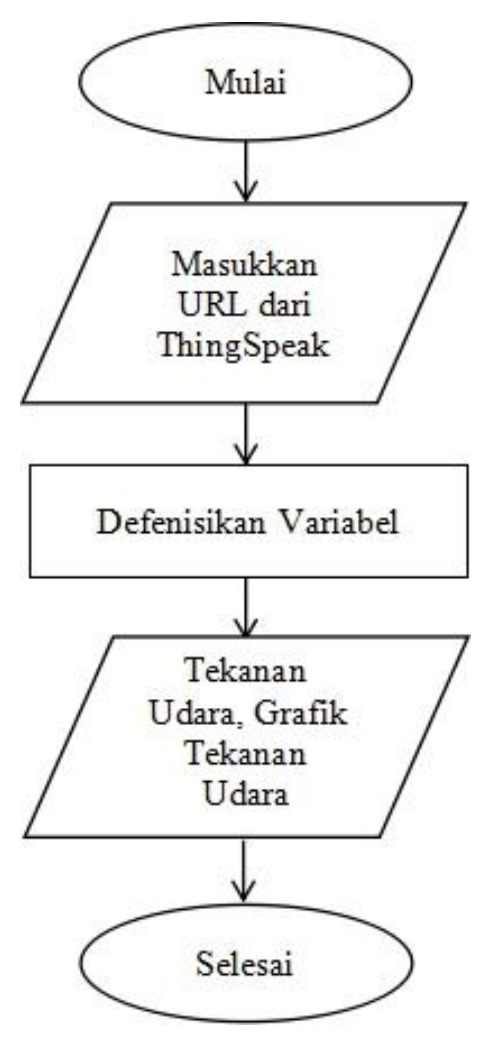

Gambar 6. Desain Perangkat Lunak App Inventor

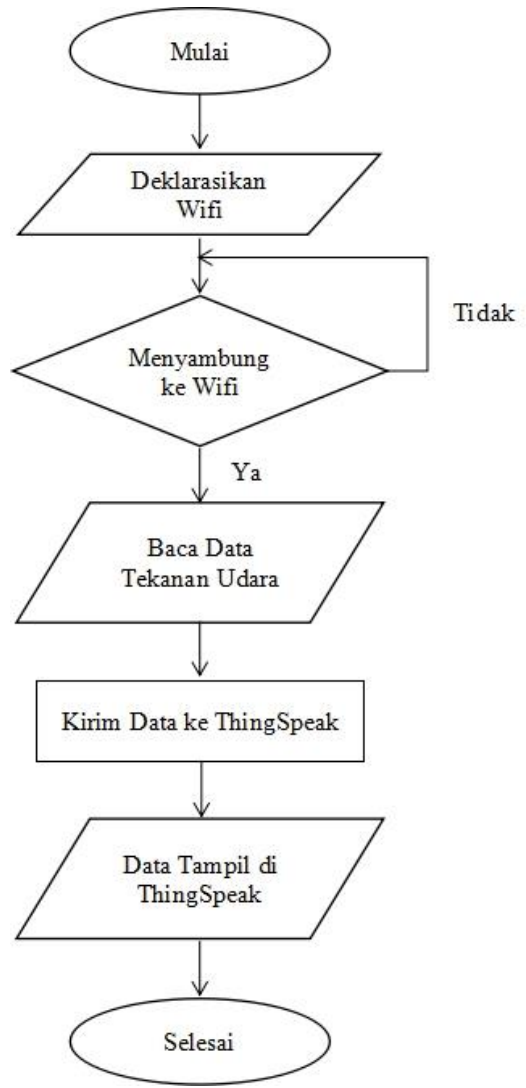

\section{Gambar 7. Diagram Alir Sistem}

Flowchart desain perangkat lunak pada NodeMCU ESP8266 dengan langkah awal yaitu Wifi yang akan digunakan dideklarasikan terlebih dahulu SSID dan passwordnya, dimana ketika sistem tersambung ke wifi maka data sensor tekanan udara akan terkirim ke ThingSpeak. Semua data tekanan udara akan tampil di ThingSpeak. Selanjutnya data yang telah terkumpul di ThingSpeakakan diplot grafik secara realtime. Jika sistem tersebut tidak terhubung ke wifi maka akan menuju ke perintah awal.Sedangkan desain perangkat lunak pada App Inventor dengan langkah awal yaitu memasukkan URL dari ThingSpeak atau Cloud. Setelah itu data yang terdapat pada ThingSpeak didefenisikan pada App Inventor. Setelah itu data tekanan udara dan grafik tekanan udara dapat ditampilkan secara realtime.

\section{HASIL DAN PEMBAHASAN}

\section{Spesifikasi Performansi}

Spesifikasi performansi dari sistem pengukuran tekanan udara menggunakan sensor DT-Sense Barometric Pressure berbasis Internet of Things dengan display smartphone merupakan pengidentifikasian setiap bagian pembentuk sistem.

Secara keseluruhan alat ukur tekanan udara ini terdiri dari satu kotak rangkaian berwarna hitam berukuran $5 \times 5 \times 10 \mathrm{~cm}$ dan satu buah smartphone. Pada kotak rangkaian terdapat sensor tekanan udara, NodeMCU ESP8266, tombol ON/OFF, tombol reset dan kabel penghubung ke catu daya. Smartphone digunakan sebagai display dari sistem pengukuran tekanan udara. Bahan dari kotak rangkaian menggunakan akrilik berukuran $3 \mathrm{~mm}$.

Dengan menggunakan App Inventor dirancang sebuah tampilan untuk 
Smartphone yang datanya diambil dari server ThingSpeak. Data yang tampil pada Smartphone dapat disimpan dan update secara realtime. Bentuk sistem dari alat ukur dapat dilihat pada Gambar 8 dan tampilan data pada Smartphone dapat dilihat pada Gambar 9.

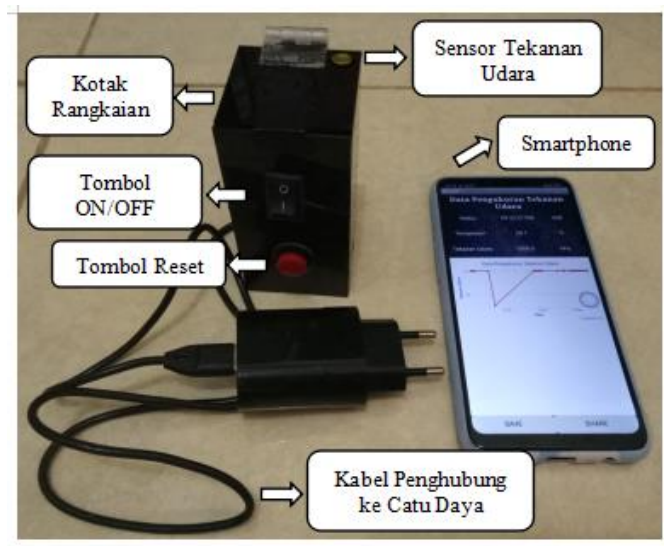

Gambar 8. Bentuk Sistem Alat Ukur Tekanan Udara
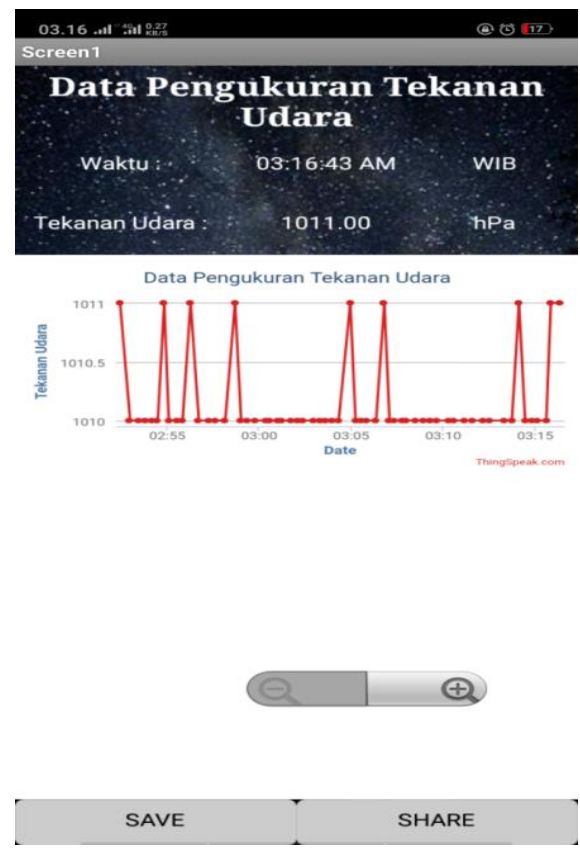

Gambar 9. Tampilan Data pada Smartphone
Gambar 9 terlihat bahwa pada tampilan terdapat waktu yang berjalan secara realtime, nilai tekanan udara yang terbaca, grafik nilai tekanan udara, tombol save, dan tombol share. Data yang tampil dapat kita simpan dengan menekan tombol save, dan data yang tampil juga dapat kita share ke perangkat yang ada.

\section{Ketepatan Pengukuran Tekanan Udara}

Untuk mengetahui ketepatan dari sistem pengukuran dilakukan pengukuran tekanan udara dengan Barometer Digital dan alat ukur tekanan udara yang dibuat.Data pengukuran dapat dilihat pada Tabel 1. Melalui perhitungan dapat ditentukan nilai rata-rata, persentase kesalahan, ketepatan relatif, dan persentase ketepatan. Rata-rata persentase kesalahan sistem yaitu $0.02965 \%$. Persentase ketepatan rata-rata sistem yaitu 99.995\%. Grafik perbandingan pengukuran tekanan udara menggunakan Barometer Digital dengan alat ukur tekanan udara dapat dilihat pada Gambar 10.

Berdasarkan Gambar 10 terlihat perbedaan nilai tekanan udara yang terbaca antara Barometer Digital dengan alat ukur tekanan udara yang telah dibuat. Hal tersebut terjadi karena adanya pembulatan dalam pembacaan nilai tekanan udara pada alat ukur yang dibuat, sedangkan nilai tekanan udara yang terbaca pada Barometer Digital angkanya dalam bentuk desimal. 


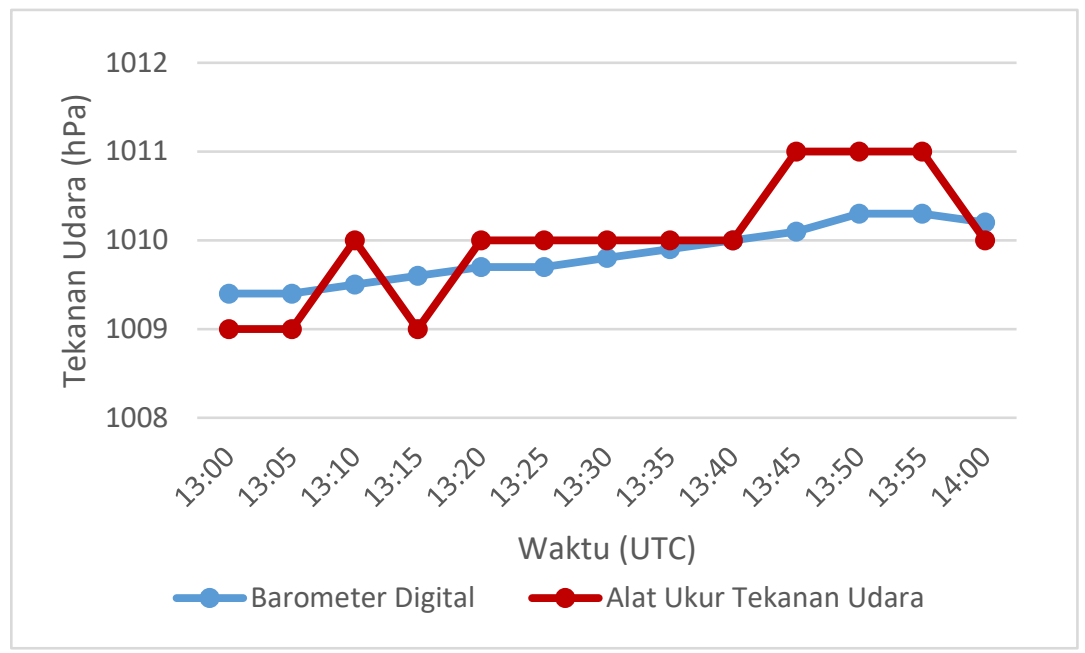

Gambar 10. Grafik Perbandingan Pengukuran Tekanan Udara menggunakan Barometer Digital dengan Alat Ukur Tekanan Udara

Tabel 1 . Data Statistik Rata-Rata Ketepatan Alat Ukur Tekanan Udara

\begin{tabular}{cccccc}
\hline $\begin{array}{c}\text { Waktu } \\
\text { (WIB) }\end{array}$ & $\begin{array}{c}\text { Tekanan Udara } \\
\text { Alat Ukur } \\
\text { Standar }(\mathrm{hPa})\end{array}$ & $\begin{array}{c}\text { Tekanan } \\
\text { Udara Alat } \\
\text { Ukur }(\mathrm{hPa})\end{array}$ & $\begin{array}{c}\text { Persentase } \\
\text { Kesalahan } \\
(\%)\end{array}$ & $\begin{array}{c}\text { Ketepatan } \\
\text { Relatif }\end{array}$ & $\begin{array}{c}\text { Persentase } \\
\text { Ketepatan } \\
(\%)\end{array}$ \\
\hline $20: 00$ & 1009.4 & 1009 & 0.0396 & 0.9996 & 99.96 \\
$20: 05$ & 1009.4 & 1009 & 0.0396 & 0.9996 & 99.96 \\
$20: 10$ & 1009.5 & 1010 & 0.0495 & 0.9995 & 99.95 \\
$20: 15$ & 1009.6 & 1009 & 0.0594 & 0.9994 & 99.94 \\
$20: 20$ & 1009.7 & 1010 & 0.0297 & 0.9997 & 99.97 \\
$20: 25$ & 1009.7 & 1010 & 0.0297 & 0.9997 & 99.97 \\
$20: 30$ & 1009.8 & 1010 & 0.0198 & 0.9998 & 99.98 \\
$20: 35$ & 1009.9 & 1010 & 0.0099 & 0.9999 & 99.99 \\
$20: 40$ & 1010 & 1010 & 0 & 1 & 100 \\
$20: 45$ & 1010.1 & 1011 & 0.0891 & 0.9991 & 99.91 \\
$20: 50$ & 1010.3 & 1011 & 0.0692 & 0.9993 & 99.93 \\
$20: 55$ & 1010.3 & 1011 & 0.0692 & 0.9993 & 99.93 \\
$21: 00$ & 1010.2 & 1010 & 0.0197 & 0.9995 & 99.95 \\
& Rata-Rata & & 0.02965 & 0.99955 & 99.995 \\
\hline
\end{tabular}

Ketelitian Pengukuran Tekanan Udara Untuk mengetahui tingkat ketelitian dari pengukuran tekanan udara ini dilakukan dengan cara mengukur tekanan udara pada kondisi yang sama. Pengukuran dilakukan sebanyak 10 kali dengan pembacaan pada alat ukur standar konstan. Data pengukuran 
dapat dilihat pada Tabel 2. Berdasarkan pengukuran ditentukan nilai rata-rata, standar deviasi, persentase kesalahan dan ketelitian. Instrumen memiliki ketelitian yang tinggi untuk pengukuran tekanan udara. Ketelitian rata-rata instrumen yaitu 0.99 dengan standar deviasi 0.7 dan kesalahan relatif yaitu $0.0098 \%$.

Berdasarkan analisis data yang dilakukan secara grafik dan statistik dapat digambarkan beberapa hasil penelitian yang sesuai dengan tujuan penelitian. Hasil penelitian yang diperoleh adalah spesifikasi performansi dan spesifikasi desain.
Spesifikasi desain meliputi ketepatan dan ketelitian dari alat ukur tekanan udara.

Dilihat dari segi ketepatan alat ukur yang dibuat, diperoleh ketepatan yang cukup tinggi dengan persentase kesalahan yang sangat kecil. Sedangkan dari segi ketelitian, alat ukur ini memiliki ketelitian yang tinggi, hal ini ditandai dengan nilai standar deviasi yang sangat kecil. Berdasarkan karakterisitik yang ditunjukkan maka alat ukur tekanan udara ini layak digunakan. Alat ukur ini dapat digunakan untuk mendukung kegiatan di Laboratorium Elektronika dan Instrumentasi serta untuk mendukung alat di Stasiun BMKG.

Tabel 2. Data Statistik Rata-Rata Ketelitian Alat Ukur Tekanan Udara

\begin{tabular}{ccccc}
\hline $\begin{array}{c}\text { Waktu } \\
\text { (WIB) }\end{array}$ & $\begin{array}{c}\text { Tekanan Udara } \\
\text { Alat Ukur } \\
\text { Standar }(\mathrm{hPa})\end{array}$ & $\begin{array}{c}\text { Tekanan Udara } \\
\text { Alat Ukur }(\mathrm{hPa})\end{array}$ & $\begin{array}{c}\text { Rata-Rata } \\
(\mathrm{hPa})\end{array}$ & $\begin{array}{c}\text { Persentase } \\
\text { Ketelitian } \\
(\%)\end{array}$ \\
\hline $10: 35$ & 1010.3 & 1011 & 1010.7 & 99.97031 \\
$10: 36$ & 1010.3 & 1011 & 1010.7 & 99.97031 \\
$10: 37$ & 1010.3 & 1011 & 1010.7 & 99.97031 \\
$10: 38$ & 1010.3 & 1011 & 1010.7 & 99.97031 \\
$10: 39$ & 1010.3 & 1011 & 1010.7 & 99.97031 \\
$10: 40$ & 1010.3 & 1011 & 1010.7 & 99.97031 \\
$10: 41$ & 1010.3 & 1011 & 1010.7 & 99.97031 \\
$10: 42$ & 1010.3 & 1010 & 1010.7 & 99.93074 \\
$10: 43$ & 1010.3 & 1010 & 1010.7 & 99.93074 \\
$10: 44$ & 1010.3 & 1010 & 1010.7 & 99.93074 \\
& \multicolumn{2}{c}{ Rata-Rata } & & 99.950525 \\
\hline
\end{tabular}

\section{KESIMPULAN}

Berdasarkan hasil pengujian dan analisis terhadap besaran fisika yang terdapat pada alat ukur tekanan dapat dikemukakan kesimpulan yaitu : Ketepatan dari alat ukur sangat tinggi yaitu pada pengukuran tekanan udara ketepatan ratarata $99.995 \%$. Ketelitian rata-rata dari alat ukur yaitu 0.99 dengan standar deviasi 0.7 dan kesalahan relatif yaitu $0.0098 \%$. 


\section{UCAPAN TERIMAKASIH}

Terima kasih kepada Universitas Negeri Padang atas Penelitian Unggulan Perguruan Tinggi Terapan 2019, Ketua Tim Dr. Yulkifli, S.Pd, M.Si., No.Kontrak : 1012/UN35.13/LT/2019

\section{DAFTAR PUSTAKA}

[1] A. P. Putera dan K. L. Toruan, "Rancang Bangun Alat Pengukur Suhu, Kelembaban dan Tekanan Udara Portable Berbasis Mikrokontroler ATMega16," $J$. Meteorol. Klimatologi dan Geofis., vol. 3, no. 2, hal. 42-50, 2016.

[2] A. Fadholi, "Study Pengaruh Suhu dan Tekanan Udara Terhadap Operasi Penerbangan di Bandara H.A.S. Hananjoeddin Buluh Tumbang Belitung Periode 1980-2010," J. Penelit. Fis. dan Apl., vol. 3, no. 1, hal. 1-10, 2013.

[3] Yulkifli, Asrizal, dan R. Ardi, "Pengukuran Tekanan Udara Menggunakan DT-Sense Barometric Presure Berbasis Sensor HP03," J. Saintek, vol. VI, no. 2, hal. 110-115, 2014.

[4] C. S. Populasi, P. Palloan, dan N. Ihsan, "Studi tentang Komparasi Data Tekanan Udara Pada Barometer Digital dan Automatic Weather Sistem (AWOS) Di Stasiun Meteorologi Hasanuddin Makasar," J. Sains dan Pendidik. Fis., vol. 8, no. 3, hal. 297-302, 2012.

[5] Yulkifli, Yohandri, dan Z. Affandi, "Pembuatan Sistem Pengiriman Data
Menggunakan Telemetri," J. Ilm. SETRUM, vol. 5, no. 2, 2016.

[6] Yulkifli, Sensor Fluxgate. Batu Sangkar: STAIN Batu Sangkar Press, 2011.

[7] A. B. P. Purba dan A. T. Sutanto, "Pengukur Suhu Kelembapan dan Tekanan Udara Berbasis Mikrokontroler ATMega32," J. Meteorol. Klimatologi dan Geofis., vol. 3, no. 1, hal. 31-37, 2016.

[8] R. Kamal, Internet of Things: Architecture and Desain Principles,. India: McGraw Hill Education, 2017.

[9] D. P. Pura, "Rancang Bangun Aplikasi Mobile Remote Control Berbasis Android Pada Robot Lego MindStrorm NXT 2.0," J. Sist. dan Teknol. Inf., vol. 2, no. 3, hal. 0-5, 2014.

[10] H. Yuliansyah, "Uji Kinerja Pengiriman Data Secara Wireless Menggunakan Modul ESP8266 Berbasis Rest Architecture," J. Rekayasa dan Teknol. Elektro, vol. 10, hal. 71, 2016.

[11] S. P. Aji, "Alat Monitoring Tetesan Infus Menggunakan Web Secara Online Berbasis ESP8266 dengan Pemograman Arduino IDE," Tugas Akhir, 2017.

[12] C. D. N. Tulle, "Monitoring Volume Cairan Dalam Tabung (Drum Silinder) Dengan Sensor Ultrasonik Berbasis Web," Tugas Akhir, 2017.

[13] K. Priyono, "Sistem Monitoring Level Reservoir SPBU Terintegrasi ThingSpeak Sebagai Server Database," Tugas Akhir, 2018. 
Handini, dkk: Rancang Bangun Sistem Pengukuran Tekanan Udara Menggunakan DT-Sense Barometric Pressure Berbasis Internet of Things dengan Tampilan pada Smartphone 